\title{
Factors Influencing the Executive and Legislative Conflict in Nigeria Political Development
}

\author{
IhemejeChidiebere C. Godswealth, Zaid B. Ahmad (Phd), JayumAnak \\ Jawan \\ Faculty of Human Ecology, Department of Politics and Government \\ Universitiputramalaysia
}

\begin{abstract}
The article examined the factor influencing the executive and legislative conflicts in Nigeria Political development. A current trend in the relationships between these organs of government has gathered greater momentum from academics, policy makers, and development organizations as well as researchers. The political dimension of development has contributed immensely in defining the nature of executive and legislative relationship. Nigeria political development has been hampered by the conflictual political relationship existing between the key actors of policy making and policy execution. Separation of Power Theory was used to explain what is needed from these key political players in the government of Nigeria. The harmony expected from these major players results to institutional stability, political development as well as defined legal institutions that protect all aspects of the Nigerian State. This paper among other things explores the following issues: the factors responsible for the executive and legislative conflicts which impede on Nigerian; the implication of this problem for the political development and the significantchallenges and prospects to Nigerian.
\end{abstract}

Keywords:-Executive, Legislature and Political Development.

\section{INTRODUCTION}

Nigeria as a countryis bedeviled by the problem of bad governance, attributed to the conflicts of the executive and legislative arms of government. Scholars have advocated several factors as responsible for this trend. This paper takes a critical look at the Executive and Legislative Conflict in Nigerian government as a makeup cause of bad governance that does not promote development. It considers the key factors responsible for this phenomenon and also analyses the implication of this problem for the political development, and the efforts of thegovernment to entrench the respect for the constitution in Nigeria.

II. SEPARATION OF POWER AS DEMOCRATIC PRINCIPLE

The political and national development of any democratic country is a function of the mutual and cordial but also genuine relation between all arms of government. Where such relation is not a cordial one, it leads to malfunction of the apparatuses of the state. The separation of powers as advocated by the founder of the liberal school of governance is to ensure that conflictis reduced to its most possible minimal. Ogolama Fineface's view is that"the guarantee of human liberty in any given government to the people is the practice of the theory of separation of powers. This theory according to Gettel implies thatdifferent bodies of persons should perform the three functions of the government. Each department (the legislature, the executive, and the judiciary) limited to its sphere of actions and within that field should be independent and supreme".

The essence of the theory of separation of powers, therefore, isbuilt on the believe that, if the executive, legislature, and the judiciary powers are vested in one person or group of individuals, such people will have unlimited powers. In such a way that they could prescribe any law, arrest anyone and even prosecute same for no reason. Since they exercise unlimited powers, they may pronounce even a falsely accused person guilty without a chance to defend himself. Through the separationof powers then, any particular group cannot prescribe, execute and adjudicate in any case at the same time. Doing this would amount to injustice.

The originof the theory of separation of power in the post-ancient Greek era democracy can be traced back to John Lock and Montesquieu. Locke posits that:It may be too great a temptation to human frailty, apt to grasp at power, for the same person who have the power of making laws also to have in their hand the power to execute them whereby they may exempt themselves from the obedience to the laws they made and suits they, both in its making and execution to their private advantage.Similarly, Montesquieu posits that;Political liberty is to be foundonly when there is no abuse of power. But consistent experience shows every man invested with power is liable to abuse it and carry his authority as far as it will go. To prevent this abuse, it is necessary from the nature 
of things that one power should be clicked on another... when the legislative and the executive powers are united in same person or body, there can be no liberty. Again there is no liberty if the judiciaryis not separated from the legislature and the executive. There would be an end of everything if the same person or body, whether of the noble or the people, were to exercise althepowers.Thus, the theory of separation of powers is made necessary by the need to preserve and ensure that theliberty of the people and the society, which was in the first place the basis for governance, is not trampled upon. Indeed the theory was developed to ensure that the society works and develops.BectsehKwagha and Robert Echinkwony identify the objectives of the doctrine of separation to include among others;

(i). Avoidance of tyranny and ultimate safeguard of labor, all arm works for peace and coexistence in the society. (ii) Efficiency is employed in the most suitable position as a result of concentration in specialize functions. Separation of powers brings about higher productivity as a result of dexterity in performance. The corollary principle of separation of powers enhances checks and balances as one arm serves as a watchdog over the other. In effect, there will be independent co-operation as each arm monitors the activities of the other to preserve human liberty.

Thus, the principle of separation of powers is premised on the need to protect the liberty of the citizens of the state, in other words, to protect the fundamental human rights of the people. While some scholars advocate for a total separation of powers, some others advocated for a system of checks and balance where it is premised on the perceived impracticality of the complete separation of powers. To these scholars, a system of checks and balance is desirable and feasible rather than absolute separation of powers which is impracticable. The power may be distinct but not separate.BeetsehKwagha and Robert Echikwonye posit that "it is germane to maintain that the value of the doctrine lies with the checks and balances which are essential to prevent an abuse of the enormous power vested in the ruler.

A separation of powers is prominent in Nigeria's constitution. From Sections 4,5, and6it outlines the respective powers of the legislature, executive and judiciary branches. However, in the light of provisions on checks and balances, the Constitution does not engender a total separation of powers because each branch has some influence over the others. For example, the legislature reviews the executive through its oversight functions, the impeachment weapon and legislative confirmation of certain executive nominees, such as ministers, commissioners, and ambassadors. Thus, the principal purpose of checks and balances is to ensure that all arms of government inter-monitor one another for efficient and good governance.

\section{A NEXUS OF EXECUTIVE AND LEGISLATIVE DISPARITY AND ITS EFFECT IN NIGERIA DEMOCRATIC SITUATION}

One does not have to look too deep into political practices in Nigeria for one to see that the principle of separation of powers and checks and balance have been over the years, mal-applied, perverted and as a matter of fact, abused in the Nigerian political reality. Beetseeh and Echikwonye conclude that;The extent this constitutional provision is applied leaves much to be derived. There is interference among the organs of government. In most cases, the executive with power dictates the tune in the functions of the other arms of government. This is an abuse of power that is contrary to the doctrine of separation of powers.

The point here is that the principles of separation of powersseem not to be very much extremely practicable, as it looks in principle. This is the case between the executive and the legislative arms of government in Nigeria.

The question that would come to mind is that, how can such a principle of separation of powers which was borne out of the need and quest to protect the people from being subjected to a tyrannical government not work well in practice? To this end, Oshio contends that

Separation of powers in its practical operation involves a sharing of government, a system of checks and balances which allow each arm of government to defend its position in the constitutional framework of government. It needs flexibility, understanding and cooperation among the arms of government with each arms recognizing the limits and enforcing them. In this way, the purpose of government is fulfilled, through the contribution from all the arms of government as partners in progress.The implication of Oshio's position is that the principles cannot work on its own; they have to be placed in the hands of those whose intention to govern are strictly the interest and wellbeing of the society as a whole. Thus, separation of powers coupled with checks and balance may not bring forth the desired result if put in the hands of ill-intentioned individuals. It should be noted that people in government do not just choose to become enemies for selfishness or enmity sake. There are therefore factors which can be held responsible for the hostility perceived in government circles.

Partisan politics and unethical godfatherism are some of the factors affecting executive-legislative relations in Nigeria. These factors have gone as far as causing both inter and intra-party conflict which has led in many cases to disputes between the executives and the legislature. There have been cases where the executive refuses to sign into law a bill passed by the legislature, on the grounds of political differences. Similarly, 
lawmakers have made attempts to unleash their power of impeachment on the executive by perceived political difference(s). Olorungbemi Simeon is of the opinion that in the Nigerian political experience,

the state lawmakers impeached elected governors without recourse to due process of law; the prime suspect in high-profile political assassination leapfrogged over the constitution and landed in the Senate; above all the executive whose constitutional duty is to maintain law and order, blatantly withheld Lagos state funds and disobeyed court orders with impunityOni Samuel following many other scholars cited series of conflicts in the executive-legislative relations of the fourth republic executive and legislature in Nigeria, he writes,

One of the early issues of discord between these two arms of government was the scrapping by President Obasanjo, of the Petroleum Trust Fund (PTF) established under Decree No. 25 of 1994. The National Assembly viewed this act as ausurpation of its constitutional responsibility of making and repealing laws...

Thus, the conflicting relationship between the executive and legislature in Nigeria is always resulting in cases where either of the two ends using more powers than it has the constitutional rights to. This amounts to tyranny and abuse of power, which creates the possibility that the liberty of the people, the very purpose, and essence of government would be violated. This amounts to the possible abuse of fundamental human rights.

\section{FACTORS INFLUENCING THE EXECUTIVE AND LEGISLATIVE CONFLICTS IN NIGERIA INCLUDE:}

\section{i) The Constitutional Provision}

The constitution is the map through which any democratic government can progress (Fasagba, 2010). He states that the constitution stipulates the powers as well as the responsibilities of the various institutions of government. The first to third republic Nigerian constitution collapsed not because the constitutionwas not good enough, but it was caused by the inability of the government elites to abide by the rules of the game (Ajayi, 2007). The Nigerian constitution made provisions for each arm of government to survive interdependently. However, these roles are conflicting most of the times. For example, the role of law making by the legislature and veto power of the executive seems to be unclear to the leaders of both organs. Whereas the executive also initiates legislation and submits to the legislature for consideration and approval sometimes, look as the legislature depend solely on the executive initiatives to pass laws. One major constitutional conflict in the executive and legislative relations emanating from the Constitution is the issue of apower vacuum in 2010 (Fasagba, 2010; Momodu\&Ika, 2013). In spite of the constitutional provisions to settling the problems in the previous governments, the fourth republic tends to chart the line of conflictual power relationships instead of harmony between the executive and legislature (Mba, 2007). Though the constitutional crisis was abated, yet the constitutional has not been amended. This conflict has degenerated into severe constitutional issues which have endangered to undermine democratic consolidation and hinder political development. (Eze, 2013).

\section{ii)Conflicts of Roles}

The role conflict has to do with respect to budget endorsement, execution and evaluation processes (Lewis, 2011). The executive and legislature underthe 1999 constitution were empowered to prepare and approve budgets of the Federation respectively. Consequently, sections 80and 81 further established the mode of approving and implementing the budgets. However, section 81, part 1, reserves the exclusive right to the executive in budget preparations. There are cases budget proposals from the executive which have been hampered by the legislature for approval. For example in 2002, the budget sent to the National Assembly for approval was gridlock for five months before it was later passed into law (Aiyede, 2005). The proposed budget was atotal of N1.06 trillion which has about of N297 billion, capital expenditure and over N588 recurrent expenditure. Instead of passing the budget the legislature, however, increased the capital allocation as well as slashing the current allocation. This does not go down well with the executive who later revised the budget estimate and proceeds with implementation of the revised version of the 2002 budget. This action prompted the legislature to embark on impeachment process against the president. But for the intervention of the party leaders in this bid, the legislatures would have had their way (Eminue, 2006).

Additionally, in 2003 similar budget conflict ensued between the executive and the National Assembly. The budget which was sent to the legislature in mid of November 2002 with thehope of passing it into law was eventually stocked and later approved by the legislature eight months after, in May and then signed into law by July 2003. Of course, the lawmakers concluded that their reason was to have time to study the budget because of its significance to the nation. (Oni, 2013). This trend in the relations does not promote political development as government business is mostly affected by this gridlock thereby making the country witness underdevelopment in many aspects of the society. Again, in 2004 budget presented was delayed approval by the National Assembly; the legislature instead increased the budget from theinitial amount of N1.089 trillion to about N1.3 trillion (Olojede, 2008). Thisdifferent role is what experts in executive and legislative relations called functional overlapping (Okon, 2013; Fasabga, 2010). However, the conflicts between the executive and legislature in the fourth republic is identified by disagreement occurred within the period. Thus, Abiodun (2000), supported this 
claim when he stated that, conflicts arose when the president demanded huge sums of money in theform of supplementary from the legislature, which the National Assembly considered unnecessary and therefore, refused to approve.

\section{iii)Perceived Executive Dominance}

Another factor affecting the executive and legislative relationship is perceived executive dominance. The administration of former President Olusegun Obasanjo, 1999 on theassumption of office went ahead to scrap the Petroleum Trust Fund established by the Military Decree in 1994. The legislature conceived his action as unconstitutional as he did not consult them before abolishing the law. Meanwhile, the Attorney-General of the Federation and Minister of Justice intervened that section 315, part a, and c, provided for the executive powers under the Constitution to modify prevailing laws. Lafenwa(2007) observed that the first republic parliamentary system in Nigeria does not only fail due to the multi-ethnic society but also because of the nature of inactive legislatures existing alongside resilient and active executive.

One of the reasons the executiveis perceived of having so many powers, especially in the Nigerian context was due to the state of prolonged Military rule. For out of the number of years Nigeria has existed from independence in 1960, the Military has ruled for 30 years as against the civilian rule of only 23 years in 2013. The essence of this is the absence of watchdog from the legislature who would have made them accountable to the people through its oversight. As this institution of lawmaking was side-lined, and support was shifted to the executive branch by the military, thereby making it more powerful. In 2007, towards the end of the Obasanjo's administration, he initiated plans conceived by the legislature as underground moves to amend the constitution to favor him for thethird term. The National Assembly through its leader debated this and later aborted this plans because the clause for the amendment of the constitution was not substantial enough to carry on with the task. This attempt of thethirdterm, however, met resistance from the legislature as themajority of them did not support it (Adedoja and Epia, 2006).

\section{iv)Oversight Function of the Legislature}

The oversight functions of the legislature in any given society cannot be overemphasized. How these oversights create conflict in the relations between executive and legislature for the development of Nigeria is what this section will look it. First and foremost, the 1979 and 1999 constitution of the Federal Republic of Nigeria provides basis and powers to the legislature's departure to promote unity and political development, section 147 (2);153, 154 and 171(4) of the Constitution. Invariably, without theoversight of the lawmakers, it is possible for the executive to govern with impunity and not accountable to any person for their actions and inactions about the public funds. This more reason it was observed by the then Secretary General of Commonwealth that, the major function of the law-makers world over include: legislation, representation, national budgeting and oversight of the government among others (Shija, 2008). During the Military era in Nigeria, the legislatures were not empowered to function effectively to hold Military Heads of States accountable. The Military are the executive heads also. They use decrees and other coercive instruments to manipulate accountability, and no one is a watchdog to their activities. Even when there is the freedom to express, these views were limited by acts and decree powers of the Military. What this result into is the suppression of the freedom of speech as well as theexecutive dominance of the functions of the legislature. This cannot promote any form of development, be it economic, social, cultural or political in nature.

In their submission to the importance of oversight (Ahmadu and Ajiboye, 2004) posit that the Nigerian legislature is empowered to conduct inquiries on all matters of governance. There is agamut of supervision performed by the legislature in the Nigerian fourth republic. And these oversights sometimes clashes with the perception of the executive which later results in conflicts of both institutional relationships. One of the Administrations so disturbed is former president Olusegun Obasanjo 1999-2007. Though Obasanjo has a high Military trait, he was admittedly infuriated by the current Legislature's antagonistic stance (Adegbamigbe, 1999). In 2006 for example, the legislature instituted a committee to investigate the alleged illegal use of thepublic fund for personal use. Before then, both the president and his vice have been accusing one another ofillicit use of money from the petroleum trust fund account. The Senate in its oversight investigated these allegations from both principal officers of the executive organ with the sole aim of punishing the offenders. However, the investigation revealed that it was the President who withdrew the fund and therefore indicted him (Vanguard, 2007). The President was not satisfied with the indictment as he alleged the Vice President manipulated the result of the investigative panel. As a result, another panel was set up, which later conducted afresh inquiry. The new panel, therefore,sort evidence from various parties and then found the Vice President guilty and recommend for his impeachment (Fasagba, 2009). While the issue of oversight power of the legislature is constitutional, through its investigative committee, the legislatures can indict the executive and recommend his impeachment if found wanting of misuse of powers. However, the constitutional immunity of the executive also protects him from facing criminal or civil actions, section 308 (1) of the 1999 constitution. 
Taiwo (2004) avers that the impeachment power of the legislature is considering a check on the administrative functions of the executive. Furthermore, oversight is not only limited to the protection of public funds. Sections 147 (2) of the 1999 constitution also extends the powers of the legislature to rectify the appointments of members of the executive council submitted to them by the President.

V.

RELATIVE NEWNESS OF DEMOCRACY TO MOST PEOPLE IN GOVERNMENT (INEXPERIENCE)

From the series of literature available for study, the researcher found out there is a gap in studying the relative newness of democracy to most people in the position of leadership in these two arms of government in Nigeria. These conflicts are attributed to inexperience from people in political power. OdukoyaAdelaja (2012) asserts that one of the factors responsible to the executive and legislative feuds is the relative newness of democracy to people at the helm of affairs, including the National Assembly. According to him, though it is certain that some people have had no previous experience in what democracy entails, themajority of these politicians are only political upstarts. He further states that, as a result of the recent military handover to civilian rule, it usher in political greenhorns and upstarts that occupy the current executive and legislative branches of government. A typical example in the fourth republic is the case of Umar Na'Abba, who was the first Speaker at the inception of thefourth republic. He was thefirst timer in this exalted position and fought to secure the independence of the legislature from the executive, thereby encountered series of political problems with him and the executive. The reason is credited to his relative youthfulness and lack of democratic experience. This cost him politically as he failed to return to the House for the second term Adelaja (2012).

VI.

SUMMARY, CHALLENGES,AND PROSPECTS

This paper concludes that there is a relationship between the Executive and the Legislature in Nigeria. This relationship under a presidential system is adopted on the notion that there must be aseparation of roles and structure of the two organs.The Executive and Legislative relationship in Nigeria is of great benefit to the citizenry and could yield more benefits if the doctrine of separation of powers is promoted to ensure theindependence of each arm and then backed up by the principle of checks and balances to promote interdependency. Executive and Legislative conflict prevent and demote national development. The rate of successful political development will depend on the healthy executive and legislative relationship based on theprinciple of democratic ethics. The political and legal framework must be in place to avoid unnecessary conflicts.Divergent interests which sometimes characterize a heterogeneous society like Nigeria accounts for the Executive and Legislative conflict especially in a nascent democracy as Nigeria. The quest for political power by both the executive and the legislative must be sorted out in themanner in which the political environment of the country is structured in its constitution. It, therefore, means that when political power is achieved, it becomes less lucrative to the occupiers (Executive and Legislature) who will channel communication and policy programs of government to thetotal liberation of the plights of the masses and other developmental needs of the country.

\section{REFERENCES}

[1] Abiodun (2000). Budget War. NewswatchMay 2000. No 14. Vol. 13.

[2] Adedoja, Tokunbo, and OkeEpia, "Anti-3rd Term Lawmakers Meet Civil Society Groups," This Day Newspaper (Lagos). April 21, 2006.

[3] Adegbamigbe, Ademola, "Jitters In The House," The News Newspaper (Lagos). August 2, 1999.

[4] Ahmadu, R.A.,andAjiboye, N. (2004).A Handbook on Legislative Practice and Procedure of the National Assembly. Abuja: National Secretariat of Nigerian Legislatures.

[5] Aiyede, Remi E. (2005). "Executive-Legislature Relations in Nigeria's Emerging Presidential Democracy." UNILAG Journal of Politics.Vol. 2.No. 1. pp. 65 - 87.

[6] Ajayi, M.O. (2007). The Soccer Pitch and the Political Arena in Nigeria. Public Lecture

[7] BeetsehKwagha and Robert Echikwonye, Separation of Powers and Sustainability of Democracy in Nigeria: A Challenge. Journal of Science and Public Policy, (Cenrensin Publications, 2011), volume 3, 27.

[8] CorlettLetjolaneet. al., Nigeria: Defending Human Rights: Not Everywhere Not Every Rights, (The Observatory Frontline, 2014), 7.

[9] Eminue, O. (2006). Executive-Legislative Relations: Some Preliminary Observations on the Budget Process. In: E.O. Ojo, ed. Challenges of Sustainable Democracy in Nigeria. Ibadan: John Archers, 155183.

[10] Eze, Raphael C (2013). An Overview of the Executive, Legislature Relations and the Consolidation of Democracy in Nigeria.International Journal of Social Sciences and Humanities Review 
[11] Fasagba (2009).Legislative Oversight under the Nigerian Presidential System.The Journal of Legislative Studies.

[12] Fasagba, Joseph Yinka. (2010). "De-Constitutionalizing? Democratic Governance in Nigeria: Assessing Executive-Legislative Handling of Executive Power Vacuum in the Fourth Republic”. Africana.pp: 7 44.

[13] Lafenwa, Stephen. A. \&Gberevbie, Daniel E. I. (2007). "Legislative Oversight and Cost of Governance in Nigeria." In Akpotor, A. S. Afolabi, A. O, Aigbokhaevbolo, M. O., Iganiga, B. O. \&Odiagbe, O. S. (eds) Cost of Governance in Nigeria. An Evaluative Analysis.Ekpoma: Ambrose Ali University Publishing House. pp: 216-244.

[14] Lewis, Peter M. (2011). Nigeria Country Report. Cape Town: University of Cape Town Centre for Social Science Report.

[15] Mbah, Peter (2007). Executive-Legislative Relations in Nigeria: The Presidency and the National Assembly, 1999 -2006. Nigeria Journal of Social Sciences.Vol. 1.

[16] Momodu\&Ika (2013).The Implications of Executive-Legislative Conflicts on Good Governance in Nigeria. Public Policy and Administration Research, 2013, 3, 8, 30-42.

[17] Odukoya, A. (2012). Party System and Political Conflicts in Nigeria's Fourth Republic. Nigeria's Democratic Experience in the Fourth Republic since 1999: Policies and Politics, 127.

[18] OgolomaFineface, the Theory of Separation of Powers in Nigeria: An Assessment, African Research Review: An International Multidisciplinary Journal, vol. 6(3), No. 26, July 2012, 127.

[19] Okon (2013).An Examination of Causes and Consequences of Conflict between Legislature and Executive in Cross River State, Nigeria.

[20] Olurungbemi Simeon, Party Conflicts and Democratic Consolidation in Nigeria, International Journal of Humanities and Social Science, Vol. 4, No. 11, (USA: Center for Promoting Ideas, 2014), 266.

[21] Oni Samuel, Legislative-Executive Relations in the Presidential System: A Study of Lagos and Ogun States, Nigeria, 1999-2011, 162.

[22] Oni, Samuel Olorunmaiye (2013). Legislature-Executive Relations in the Presidential System: A Study of Lagos and Ogun States, Nigeria, 1999-2011.

[23] Oshio P. E., Separation of Powers and the Purposive Approach to the Interpretation of the 1999 Constitution, 3. http://www.justice.gov.uk/Osio.purposive.approach/pdf, accessed 16 February 2015.

[24] P. Laslett (ed.) Two Treatises of Government, (Cambridge: Cambridge University Press, 1988),

[25] Shija, W.F. (2008). The Secretary General's File. In: Commonwealth Parliamentary Association Secretariat, UK First Reading, 14 May.

[26] Taiwo, Israel. O. \&Fajingbesi, Adeyemi.A. (2004).Fiscal Federalism and Democratic Governance in Nigeria. Ibadan: National Centre for Economic Management and Administration (Nigeria).

[27] Yusuf Ali, Separation of Powers under the 1999 Constitution of the Federal Republic of Nigeria: A Critical Review. 